\title{
Proteomics-based analysis reveals that Verticillium dahliae toxin induces cell death by modifying the synthesis of host proteins
}

\author{
Chengjian Xie $\cdot$ Chunyan Wang $\cdot$ \\ Xiaokun Wang $\cdot$ Xingyong Yang
}

Received: 7 February 2013/Accepted: 26 April 2013/Published online: 16 July 2013

(c) The Author(s) 2013. This article is published with open access at Springerlink.com

\begin{abstract}
Verticillium dahliae is one of the most destructive soil-borne fungal pathogens that cause vascular wilt diseases in a wide range of important crop plants, including cotton. However, the mechanisms used by this pathogen to infect cotton have not been fully elucidated. In the present study, we first investigated changes in protein abundance during the initial interaction between cotton roots and $V$. dahliae. Among the proteins that were upregulated upon infection, some were related to reactive oxygen species (ROS); among those downregulated upon infection were proteins involved in normal metabolism or cell structure. Further experiments confirmed that a sudden release of ROS and cell death accompany $V$. dahliae infection in the cotton vasculature. Further analysis indicated that a culture supernatant of $V$. dahliae induced lesion formation in tobacco leaves; de novo protein synthesis not active gene expression was required for this induction. Lesion formation was dependent on the age of leaves, but neither the known ROS burst nor the ubiquitin/ $26 \mathrm{~S}$ proteasome system are prerequisites.
\end{abstract}

Keywords Verticillium dahliae Cotton . Root proteome $\cdot$ Cell death $\cdot$ ROS

Electronic supplementary material The online version of this article (doi:10.1007/s10327-013-0467-1) contains supplementary material, which is available to authorized users.

C. Xie $\cdot$ C. Wang $\cdot$ X. Wang $\cdot$ X. Yang $(\bowtie)$

The College of Life Science, Chongqing Normal University, Chongqing 401331, China

e-mail: yangxy94@swu.edu.cn

\section{Introduction}

Verticillium wilt, a vascular disease of cotton that substantially reduces cotton production every year, is caused by the soil-borne fungus Verticillium dahliae Kleb. The microsclerotial form of $V$. dahliae can remain viable in the soil for more than 20 years (Wilhelm 1955). In 1967, the pathogen was identified as the causal agent of this important disease of cotton under field conditions, and it has been a major threat to cotton production since then (Fradin and Thomma 2006).

Verticillium dahliae generally enters the cotton plant either by penetrating roots or via wounds in root tissues (Vallad and Subbarao 2008). After penetrating the cortex of the root, the fungus passes through the endodermis, invades the xylem vessels, eventually reaching the aerial parts of the plant (Tzima et al. 2011). Typical disease symptoms may comprise wilting, stunting, leaf necrosis, vascular plugging and brown vascular discoloration (Fradin and Thomma 2006). There are currently no fungicides available to control Verticillium wilt once plants have been infected (Klosterman et al. 2009).

Despite the economic importance of Verticillium wilt, not much is known about the molecular mechanisms and crucial components underlying this disease (Klosterman et al. 2009). Historically, there are two seemingly contradictory hypotheses concerning the mechanism of Verticillium wilt. One hypothesis states that Verticillium wilt results from toxin activity, whereas the other states that it is predominantly the result of vessel occlusion in the plant (Fradin and Thomma 2006). Some studies suggest that crude $V$. dahliae extracts containing some phytotoxic factors, such as protein-lipopolysaccharide complex (PLPC), glycoproteins, small peptides and/or cell-wall-degrading enzymes, can damage leaf and root cell membranes, 
resulting in ion leakage (Gour and Dube 1985). Meyer's group purified PLPC from culture filtrates of a virulent $V$. dahliae strain, and this PLPC showed high binding activity on cotton plasma membranes and protoplasts, especially from root tissues (Meyer et al. 1994). However, evidence for a dominant role for these toxins in causing Verticillium wilt is often inconsistent and contradictory and therefore not universally accepted (Cooper 2000).

Studies on tomato Verticillium wilt have shown that in this host, vessel occlusion is the primary cause of water stress (Street and Cooper 1984). The occlusion can be due to a physical blockage of the xylem by the pathogen or due to host defense responses that result in vessel plugging (Fradin and Thomma 2006). In recent years, some genes related to $V$. dahliae pathogenicity have been identified, such as a mitogen-activated protein kinase (VMK1) (Rauyaree et al. 2005), a cAMP-dependent protein kinase A (VdPKAC1) (Tzima et al. 2010), a glutamic acid-rich protein (VdGARP1) (Gao et al. 2010) and a sucrose nonfermenting 1 gene (VdSNF1) (Tzima et al. 2011). Proteins that can induce plant cell death have also been isolated from a culture supernatant of $V$. dahliae such as VdNEP (Wang et al. 2004); however, there is still doubt whether any of these play key role in $V$. dahliae pathogenicity (Zhou et al. 2012). So the critical elements and the molecular mechanisms involved in pathogenicity of Verticillium wilt have not yet been discovered.

Because the early biochemical responses of cotton roots after $V$. dahliae infection can reflect the plant reaction to $V$. dahliae invasion, in the present study, we use proteomic methods to identify proteins involved in roots responses to $V$. dahliae and investigate the response of cotton to $V$. dahliae infection.

\section{Materials and methods}

Conidial culture, plant growth, and inoculation system

Verticillium dahliae isolate V9 (a highly virulent strain isolated from upland cotton that causes defoliation) was obtained from the Department of Plant Protection, Southwest University, China. The strain was used throughout the study and stored in our laboratory. The isolate was grown on potato dextrose broth (PDB) (200 g potato, $20 \mathrm{~g}$ glucose, and distilled water; final volume, $1 \mathrm{~L}$ ) at $25^{\circ} \mathrm{C}$ for 20 days. Acid-delinted upland cotton seeds (Gossypium hirsutum cv. Xinluzao-13) were kindly provided by Dr. Wangfeng Zhang (Shihezi University, China). The seeds were germinated in sterile distilled water (containing $0.9 \%$ $\mathrm{v} / \mathrm{v}$ hydrogen peroxide) for 2 days at $25^{\circ} \mathrm{C}$. Germinated seeds were grown in sterile vermiculite under artificial light (12-h photoperiod at $500 \mu \mathrm{mol} \mathrm{m} \mathrm{m}^{-2} \mathrm{~s}^{-1}$ ) at $25^{\circ} \mathrm{C}$ and watered using autoclaved MS basal liquid medium (Murashige et al. 1962) every third day for 15 days. At the fourth true-leaf stage of cotton seedlings, the roots of the seedlings were dipped into a conidial suspension of $V$. dahliae $\left(10^{6}\right.$ conidia/mL) or into sterile distilled water without conidia as the control. The seedlings were incubated at $25{ }^{\circ} \mathrm{C}$ with a 12 -h light/12-h dark photoperiod and $90 \%$ relative humidity, then harvested at various times and rinsed using deionized water. The roots were cut, patted dry between paper towels, frozen in liquid nitrogen and then stored at $-80{ }^{\circ} \mathrm{C}$ until protein extraction.

\section{Protein extraction and quantification}

Proteins were extracted from cotton roots using our previously described method with minor modifications (Xie et al. 2009). The sample was ground in liquid nitrogen in a prechilled mortar containing $10 \% \mathrm{w} / \mathrm{v}$ silicon dioxide and $10 \% \mathrm{w} / \mathrm{v}$ polyvinylpolypyrrolidone (PVPP). The finely ground powder $(\sim 1 \mathrm{~g}$ per tube) was immediately transferred into a $50 \mathrm{~mL}$ centrifuge tube and weighed. The sample was resuspended in $10 \mathrm{~mL}$ of extraction buffer [0.1 M Tris- $\mathrm{HCl}, \mathrm{pH} 8.0$, containing $30 \% \mathrm{w} / \mathrm{v}$ sucrose, $2 \%$ w/v SDS, $1 \mathrm{mM}$ phenyl methyl sulfonyl fluoride (PMSF), $2 \% \mathrm{v} / \mathrm{v} \beta$-mercaptoethanol], and $7 \mathrm{~mL}$ of $1 \mathrm{M}$ Tris-saturated phenol ( $\mathrm{pH} 8.0)$ was added. The mixture was homogenized and incubated on ice for $5 \mathrm{~min}$, the upper phenol phase was collected, and this extraction step was repeated once again. The phenol phases were combined in a new tube and washed once with an equal volume of extraction buffer, and the proteins were precipitated with 5 volumes of $0.1 \mathrm{M}$ ammonium acetate in methanol overnight at $-20^{\circ} \mathrm{C}$. After centrifugation at $12,000 \times g$ for $15 \min \left(4^{\circ} \mathrm{C}\right)$, the protein pellets were washed once with $3 \mathrm{~mL}$ of methanol and then washed twice with $3 \mathrm{~mL}$ of cold $80 \% \mathrm{v} / \mathrm{v}$ acetone in water. The pellets were dried in a cold vacuum dryer for $10 \mathrm{~min}$ and then resuspended in lysis buffer ( $7 \mathrm{M}$ urea, $2 \mathrm{M}$ thiourea, $4 \%$ w/v CHAPS, $65 \mathrm{mM}$ dithioithreitol (DTT), and $0.5 \%$ $\mathrm{v} / \mathrm{v}$ carrier ampholytes, $\mathrm{pH} 3-10$ (nonlinear gradient) and shaken for $1 \mathrm{~h}$ (IKA Vortex Genius 3, Staufen, Germany). After centrifugation at $15,000 \times g$ for $20 \mathrm{~min}$ to remove debris, the supernatant was collected. Protein concentration was determined using the Bradford (1976) method with bovine serum albumin as a standard.

\section{Two-dimensional gel electrophoresis}

The first electrophoresis was performed using immobilized $\mathrm{pH}$ gradient (IPG) strips $(13 \mathrm{~cm}, \mathrm{pH} 3-10$ nonlinear gradient; GE Healthcare, Piscataway, NJ, USA) on an IPGphor isoelectric focusing (IEF) system (Amersham Pharmacia, San Francisco, CA, USA). The IPG strips were rehydrated with $250 \mu \mathrm{L}$ of rehydration buffer (containing 
$370 \mu \mathrm{g}$ proteins), and the IEF was then done at $20{ }^{\circ} \mathrm{C}$ as follows: active rehydration at $30 \mathrm{~V}$ for $12 \mathrm{~h}, 200 \mathrm{~V}$ for $2 \mathrm{~h}$, $500 \mathrm{~V}$ for $3 \mathrm{~h}, 1,000 \mathrm{~V}$ for $4 \mathrm{~h}, 8,000 \mathrm{~V}$ for $5 \mathrm{~h}$, with a gradient increase in voltage between 8,000 and 40,000 V. After IEF, the proteins in the strips were reduced with $1 \%$ w/v DTT in $10 \mathrm{~mL}$ of equilibration buffer (6 M urea, $20 \%$ w/v glycerol, $2 \%$ w/v SDS, and $50 \mathrm{mM}$ Tris- $\mathrm{HCl}, \mathrm{pH} 8.8$ ) for $15 \mathrm{~min}$ and alkylated with $2.5 \% \mathrm{w} / \mathrm{v}$ iodoacetamide in $10 \mathrm{~mL}$ of equilibration buffer for $15 \mathrm{~min}$. The strips were transferred onto vertical $10.5 \%$ w/v SDS-PAGE selfcast gels. The second electrophoresis (SDS-PAGE) was performed on an Amersham Hoefer SE600 system (Amersham Pharmacia) at $10 \mathrm{~mA}$ for $1 \mathrm{~h}$ and $20 \mathrm{~mA}$ for $6 \mathrm{~h}$ at $15{ }^{\circ} \mathrm{C}$.

Protein visualization and image analysis

The 2D gel was stained with blue silver (Candiano et al. 2004). The gel was fixed in a solution of $40 \% \mathrm{v} / \mathrm{v}$ methanol and $10 \% \mathrm{v} / \mathrm{v}$ acetic acid for $30 \mathrm{~min}$, washed in distilled water four times for $15 \mathrm{~min}$, and finally incubated in a staining solution $(0.12 \% \mathrm{w} / \mathrm{v}$ Coomassie brilliant blue G-250, $10 \%$ w/v ammonium sulfate, $10 \%$ w/v phosphoric acid, $20 \% \mathrm{v} / \mathrm{v}$ methanol) overnight with gentle shaking. The gel was decolorized in distilled water. After the 2D gel was stained with blue-silver, it was scanned using an image scanner (Amersham Pharmacia). The images from the 0-, 24-, and 72-h samples were analyzed using Image Master 2D Platinum Version 5.0 Analysis Software (Amersham Pharmacia) according to the user's manual. The density of each spot was determined by the software and normalized against the total gel density. To ensure reproducibility, we did the experiment three times independently for each time point (root samples harvested from at least three seedlings at each time), and Student's $t$ test was used to determine any significant differences among samples harvested at the same time $(p<0.05)$.

\section{Protein identification and database search}

Spots of interest were excised using a modified plastic pipette tip. The bottom of a $200 \mu \mathrm{L}$ pipette tip was cut off such that its opening was approximately $1.5 \mathrm{~mm}$ in diameter. These excised spots were transferred to a microcentrifuge tube. The gel particles were washed twice with deionized water, and $50 \mu \mathrm{L}$ decolorizing solution $[50 \mathrm{mM}$ $\mathrm{NH}_{4} \mathrm{HCO}_{3} / \mathrm{CH}_{3} \mathrm{CN}$ (1:1)] was added. The samples were vortexed for $20 \mathrm{~min}$ at $37{ }^{\circ} \mathrm{C}$, and the decolorization step was repeated until the blue color disappeared. To shrink the gel particles, $50 \mu \mathrm{L}$ acetonitrile was added until the particles became white. The gel particles were dried in a vacuum centrifuge for $10 \mathrm{~min}$ and mixed with a $20 \mu \mathrm{L}$ solution of $10 \mathrm{mM}$ DTT in $25 \mathrm{mM} \mathrm{NH}_{4} \mathrm{HCO}_{3}$ for $1 \mathrm{~h}$ at $56{ }^{\circ} \mathrm{C}$ to reduce the proteins. At ambient temperature, the gels were dried in a vacuum centrifuge for $30 \mathrm{~min}$ before incubation in $20 \mu \mathrm{L}$ alkylation solution (50 mM iodoacetamide in $25 \mathrm{mM}$ $\mathrm{NH}_{4} \mathrm{HCO}_{3}$ ) for $45 \mathrm{~min}$ in the dark. Several wash steps were performed in succession: $25 \mathrm{mM} \mathrm{NH}_{4} \mathrm{HCO}_{3}(2 \times 10 \mathrm{~min})$, $25 \mathrm{mM} \mathrm{NH} \mathrm{NCO}_{3}$ in $50 \% \mathrm{v} / \mathrm{v} \mathrm{CH}_{3} \mathrm{CN}(2 \times 10 \mathrm{~min})$, $\mathrm{CH}_{3} \mathrm{CN}$ (10 min). The gel particles were completely dried in a vacuum centrifuge for $10 \mathrm{~min}$ and enzymatically digested at $37{ }^{\circ} \mathrm{C}$ overnight with $5 \mathrm{ng} / \mathrm{mL}$ trypsin. Digested peptides were extracted in $0.1 \% \mathrm{v} / \mathrm{v}$ trifluoroacetic acid (TFA) in $50 \% \mathrm{CH}_{3} \mathrm{CN}$ and analyzed in the Ultraflex TOF/TOF (Bruker, Germany). Maldi Matrix: a-cyano-4-hydroxy-cinnamic acid $\left(4 \mathrm{mg} / \mathrm{mL}, 70 \%\right.$ v/v acetonitrile: $30 \mathrm{ddH}_{2} \mathrm{O}$, containing $0.1 \% \mathrm{v} / \mathrm{v}$ TFA). Parent ion masses were measured in the delayed extraction mode with an accelerating voltage of $20 \mathrm{kV}$. The autolytic fragments of trypsin acted as internal calibrants. The spectra were acquired in a positive reflectron mode $(20 \mathrm{kV})$ and collected within the mass range of 700-4200 $\mathrm{Da}$. Mass fingerprint spectra were processed with the FlexAnalysis 2.0 software (Bruker). Database searches were performed using the online Mascot search engine (http://www.matrixscience.com). Because a complete cotton protein database is not available, the searches were run against all available higher plant proteins. The following search parameters were applied using the NCBI protein database: a mass tolerance of $0.2 \mathrm{Da}$ and one missed cleavage was allowed; carboxyamidomethylation of cysteine was specified because fixed modification and oxidation of methionine were allowed as variable modifications.

In vivo detection of $\mathrm{H}_{2} \mathrm{O}_{2}$ in cotton roots

$\mathrm{H}_{2} \mathrm{O}_{2}$ was detected in the roots of cotton using 3,3'-diaminobenzidine (DAB) as a substrate (Orozco-Cardenas and Ryan 1999). Briefly, the primary roots were excised from seedlings with a knife and immersed in a solution containing $1 \mathrm{mg} / \mathrm{mL}$ DAB dissolved in $\mathrm{HCl}$-acidified $(\mathrm{pH}$ 3.8) distilled water for $5 \mathrm{~h}$ at $25^{\circ} \mathrm{C}$. The surface dye was washed with distilled water, and root pieces were fixed and decolorized in a boiling acetic acid-glycerolethanol solution $(1: 1: 3)$ for $10 \mathrm{~min}$. The samples were then stored in $60 \% \mathrm{v} / \mathrm{v}$ glycerol for microscopic examination. Very thin, free-hand sections of root pieces were mounted on a glass slide in microscopy solution and examined with a light microscope Nikon 80i (Nikon, Tokyo, Japan).

Detection of dead plant cells in cotton tissues

Staining with trypan blue to detect dead cells in cotton tissues was done as described by van Wees (2008) with some modification. The trypan blue working solution was prepared by diluting the stock solution $(10 \mathrm{~g}$ phenol, 
$10 \mathrm{~mL}$ glycerol, $10 \mathrm{~mL}$ lactic acid, $10 \mathrm{~mL}$ water and $0.02 \mathrm{~g}$ trypan blue) with ethanol $(96 \% ; 1: 2 \mathrm{v} / \mathrm{v})$. Whole seedlings were harvested and transferred to plastic test tubes with a lid containing diluted trypan blue solution. The tubes were boiled in the staining solution for $1 \mathrm{~min}$ and left overnight in the solution. Samples were stored in $60 \%$ glycerol. Transverse and longitudinal hand sections of cotton stems and roots were cut using a razor blade and mounted on glass slides in $60 \%$ glycerol and examined with the light microscope.

Preparation of crude culture supernatant of $V$. dahliae and infiltration experiments

To prepare a crude culture supernatant for $V$. dahliae, we cultured $V$. dahliae in PDB for 20 days. The culture was centrifuged at $12,000 \times g$ for $15 \min \left(4{ }^{\circ} \mathrm{C}\right)$. The supernatant was filtered twice through Whatman filter paper (Maidstone, Kent, UK) and observed with a light microscope to ensure the removal of all propagules of $V$. dahliae. In the tests on supernatant pathogenicity, $10 \mathrm{~mL}$ of $V$. dahliae supernatant was poured onto sterile vermiculite for root-dip inoculation. For the cotyledon infiltration, cotton cotyledons were vacuum-infiltrated with either $50 \mu \mathrm{L}$ of $V$. dahliae supernatant or a mixture of supernatant and inhibitors.

\section{DPI, MG132, ActD and CHX treatments}

Diphenyleneiodonium (DPI) (NADPH oxidase inhibitor), actinomycin D (ActD) (inhibitor of RNA synthesis) and $\mathrm{N}$-benzyloxycarbonyl(Z)-Leu-Leu-leucinal (MG132) (26S proteasome-specific inhibitors) were dissolved in DMSO, and cycloheximide (CHX) (protein synthesis inhibitor) was dissolved in methanol. Tobacco (Nicotiana tabacum cv. Xanthi) leaves were vacuum-infiltrated with $50 \mu \mathrm{L}$ of $V$. dahliae supernatant containing either these inhibitors or DMSO (methanol) only. The same volume of $\mathrm{ddH}_{2} \mathrm{O}$ containing the inhibitors or DMSO (methanol) was used as a negative control. To prepare crude $V$. dahliae upernatant, we cultured $V$. dahliae in PDB for 20 days. The culture was centrifuged at $12,000 \times g$ for $15 \mathrm{~min}\left(4^{\circ} \mathrm{C}\right)$. The supernatant was filtered twice through Whatman filter paper and observed with a light microscope to ensure the absence of $V$. dahliae.

\section{Results and discussion}

Proteomics analysis of cotton roots during early infection by $V$. dahliae

In our study, acid-delinted cotton seeds were grown in sterile vermiculite under artificial light and MS liquid medium (Murashige and Skoog 1962) was autoclaved to ensure that growth of other microorganisms was as much as possible restricted. The infected seedlings showed significant and consistent dehydration and wilt symptoms in comparison with the control plants $72 \mathrm{~h}$ after inoculation with $V$. dahliae (Fig. 1). Later, the seedlings developed typical leaf lesions and became defoliated (from base to apex) (Fig. S1a-c), and $V$. dahliae was isolated from the stems 25 days after inoculation (Fig. S1d).

\section{Detection of differentially expressed proteins}

To examine the initial interaction between cotton roots and $V$. dahliae, we harvested seedling root tissue at 0,24 , and $72 \mathrm{~h}$ after $V$. dahliae inoculation because the infected seedlings were significantly dehydrated and wilted by $72 \mathrm{~h}$ after $V$. dahliae inoculation (Fig. 1). Every sample for protein extraction included at least three cotton seedlings to reduce potential differences among plants. The proteins were analyzed on two-dimensional (2D) gels using pH 3-10 nonlinear gradient strips and $10.5 \%$ SDS-PAGE. On average, $830 \pm 11$ protein spots were detected on the gels after blue-silver staining (Fig. S2). Fifteen differentially expressed protein spots were identified (Table 1). One protein (Fig. 2c, spot No. 15) was significantly upregulated, whereas 10 (Fig. 2a, spot Nos. 1-10) were suppressed. Accumulation of four proteins peaked $24 \mathrm{~h}$ after inoculation with $V$. dahliae (Fig. 2b, spot Nos. 11-14). The proteins that were differentially regulated during early infection by $V$. dahliae are highlighted in Fig. 2. The proteins identified belong to various classes of defense- or compatibilityrelated plant proteins, including those related to pathogenesis (PR proteins), reactive oxygen species (ROS), protein folding and modification, glycolysis and energy generation and others. In general, however, many of these proteins are associated with ROS regulation and cell death. These observations will be detailed in the following section.

\section{Proteins related to ROS regulation}

To protect against oxidative damage, plants have developed a wide range of antioxidant systems that scavenge excessive ROS (Ahsan et al. 2008). In this respect, protein spots b11-14 (Fig. 2) showed a temporary upregulation; their expression increased by $24 \mathrm{~h}$ and subsequently decreased by $72 \mathrm{~h}$ after inoculation. Temporarily upregulated proteins that have a potential role in modulating plant responses to ROS were also reported for cotton infected by Thielaviopsis basicola (Coumans et al. 2009). Spot b11 (Fig. 2), S-adenosylmethionine (SAM) synthetase, can be determined through its action as a precursor for intracellular glutathione (GSH, a major cellular antioxidant) or direct radical scavenging (Evans et al. 1997; 
Fig. 1 Cotton seedlings without wilting symptoms after inoculation with sterile water (a) or with typical wilt symptoms after inoculation with Verticillium dahliae (b).

Cotyledons of water control (c) and infected plant (d). All images were taken at $72 \mathrm{~h}$ after inoculation
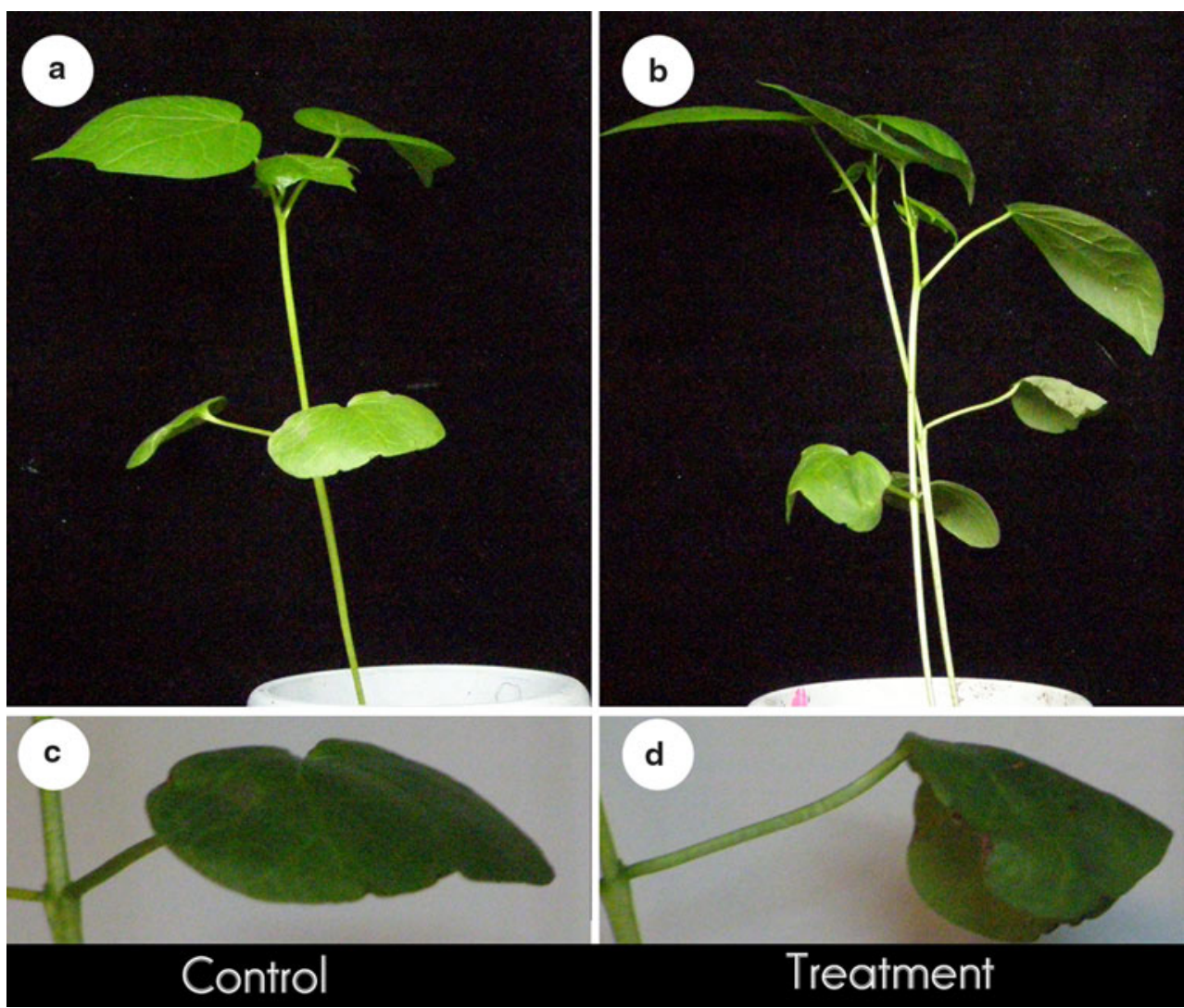

Tchantchou et al. 2008). Ascorbate peroxidase (APX) (Fig. 2, b12) and its isozyme APX1 (Fig. 2, b13) play a key role in scavenging ROS to protect cells of algae and higher plants (Davletova et al. 2005). Their expression was responsive to biotic and abiotic stress (Shigeoka et al. 2002). The family of pathogenesis-related-10 proteins (PR10) (Fig. 2, b14) is usually induced upon attack by various pathogens (El-kereamy et al. 2009). Moreover, some research suggests that PR-10 expression can be induced directly by ROS and is a marker for oxidative stress in plants (Mur et al. 2000). Phosphoglycerate kinase (Fig. 2, spot c15) is an enzyme that catalyzes the formation of ATP (Varga et al. 2009); it is a biomarker for oxidative stress and can be induced by environmental stress (Jang et al. 2008). In summary, all these proteins (Fig. 2, spot b11-14 and c15) are related to ROS. The significant upregulation suggests that infection by $V$. dahliae leads to an ROS burst in the cotton tissues; however, further experimental is needed to detect ROS in cotton tissue.

Proteins related to cell death

The proteins that had decreased in level by $72 \mathrm{~h}$ after inoculation were involved in glycolysis, energy metabolism, phosphoglycerate metabolism, and potentially in cell structure modifications. Among these proteins, glyceraldehyde-3-phosphate dehydrogenase (GAPDH) (Fig. 2, a1 and a2) and enolase (Fig. 2, a3), enzymes involved in glycolysis (Pancholi 2001; Tarze et al. 2007), are abundantly expressed in most cells (McAlister and Holland 1982). Malate dehydrogenase (MDH) (Fig. 2, a4) is involved in the citric acid cycle and glyoxylate cycle. Qin et al. (2009), while investigating fruit senescence, discovered that protein oxidation is accompanied by a loss of catalytic activity of MDH. Ubiquitin modification (Fig. 2, a5) and heat-shock proteins (HSPs) (Fig. 2, a6) are involved in the regulation of protein function and location in plants (Acconcia et al. 2009). The ubiquitin/26S proteasome system is involved in plant-microbe interactions and plant defense (Dielen et al. 2010), and most HSPs have strong cytoprotective effects and ensure plant homeostasis (Baniwal et al. 2004). Transitional endoplasmic reticulum ATPase (TER ATPase) (Fig. 2, a7 and a8) binds ubiquitinated proteins and is necessary for the export of unfolded proteins from the ER to the cytoplasm, where they are degraded by the proteasome (Zhang et al. 1994). Short et al.'s (2007) study suggests that TER ATPase and HSPs are involved in apoptosis. Actin (Fig. 2, a9) and alphatubulin (Fig. 2, a10), both components of the cytoskeleton, are commonly used to normalize molecular expression 


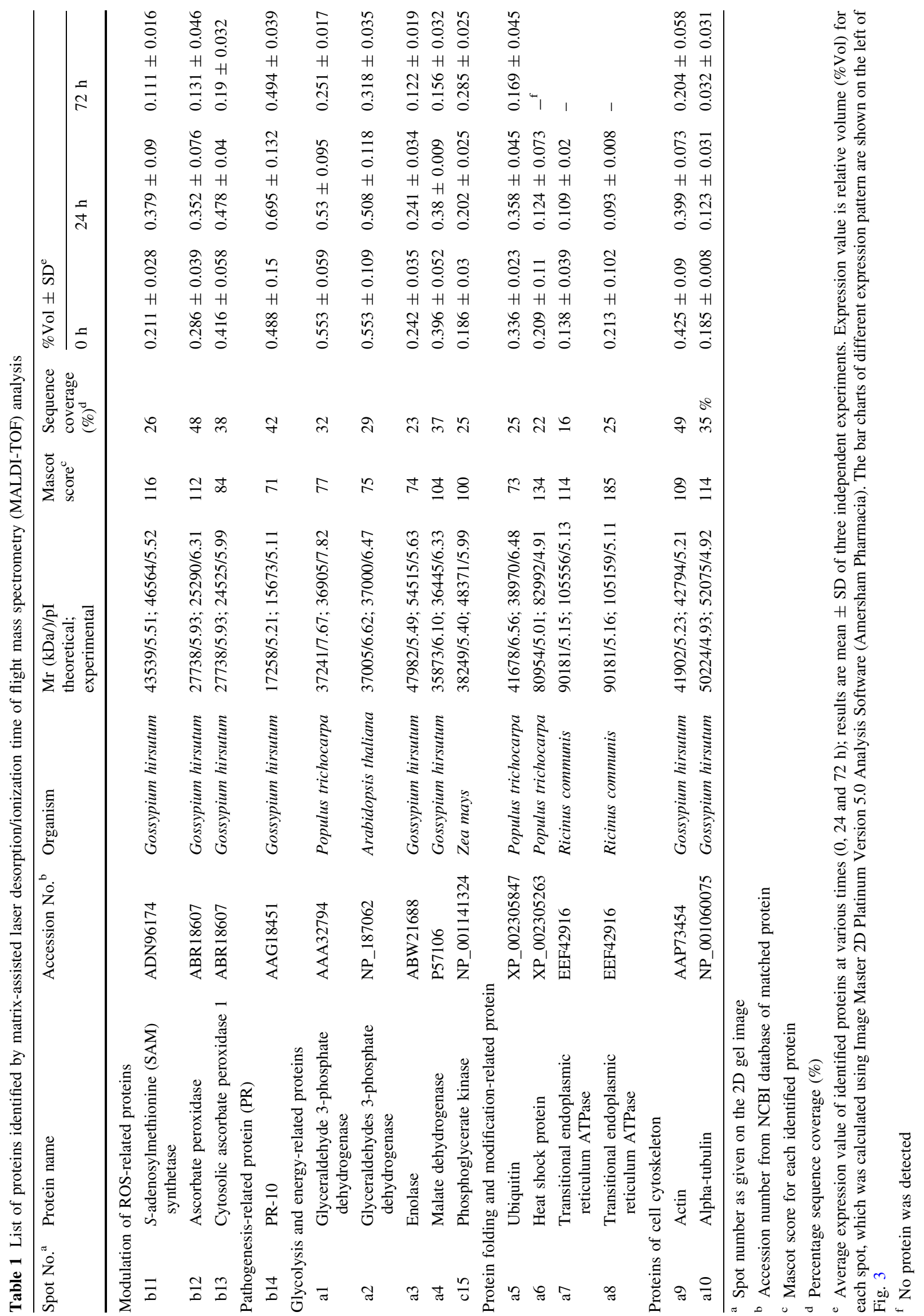



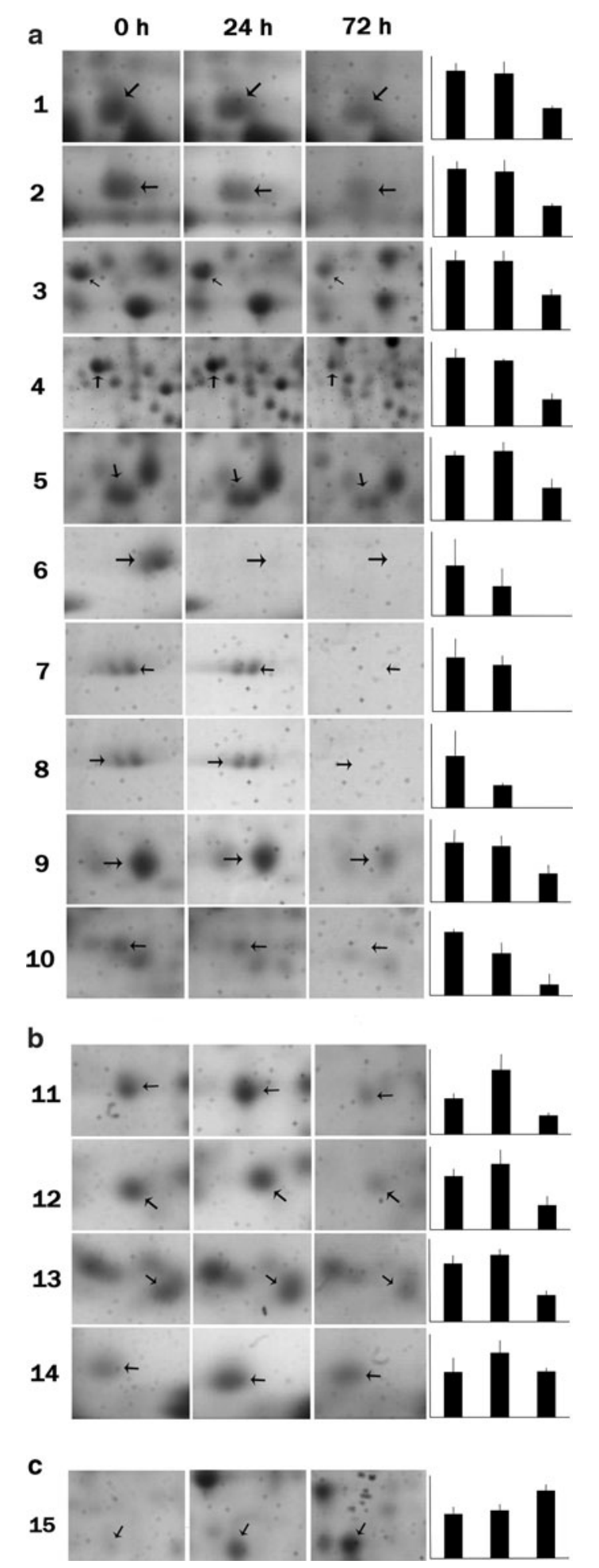

Fig. 2 Magnification of spots of differentially expression proteins on the two-dimensional gel electrophoresis gel of protein samples in cotton roots at 0-, 24-, and 72-h after inoculation with Verticillium dahliae. a Downregulated proteins, spot No. 1-10; b temporary upregulated proteins at $24 \mathrm{~h}$, spot No. 11-14; c upregulated proteins, spot No. 15. Bar graphs on the right show mean change in protein levels at each time (left to right, 0-, 24-, and 72-h); error bars represent the standard deviation of three repetitions studies because of their functions as endogenous housekeeping genes (Ruan and Lai 2007). In summary, these downregulated proteins participate in cell metabolism, structure, and stability and are expressed at a high level when the physiological status of cotton is normal. At $72 \mathrm{~h}$ after $V$. dahliae inoculation, the downregulation of these two proteins could indicate degradation of cell structures and necrosis in cotton roots, but further experimental evidence is needed.

ROS accumulation and cell death in cotton roots after infection with $V$. dahliae

The generation of ROS in cotton roots after infection with $V$. dahliae was monitored using the DAB staining assay, an efficient method for detecting $\mathrm{H}_{2} \mathrm{O}_{2}$ accumulation or localization, an indicator of ROS generation (OrozcoCardenas and Ryan 1999). As shown in Fig. 3d, a deepbrown polymerization product was clearly seen in cotton roots $72 \mathrm{~h}$ after $V$. dahliae inoculation, but was absent in control plants (Fig. 3c), indication that cotton generated ROS, as the so-called oxidative burst, after infection with $V$. dahliae, consistent with the results of Robb et al. (2012). To examine cell death after infection with $V$. dahliae in more detail, we stained infected stem and root tissue of cotton seedlings with trypan blue to visualize dead cells (van Wees 2008). At $72 \mathrm{~h}$ after V. dahliae inoculation, numerous blue-stained cells were observed around the vasculature (Fig. $3 \mathrm{f}, \mathrm{h}, \mathrm{j}$, and $\mathrm{l}$ ). In contrast, the control plants treated with water had no blue-stained cells in these areas; only a slight background color was present (Fig. 3e, g, i, and k).

Culture supernatant of $V$. dahliae induces cotton cell death

Phytotoxins or effectors secreted by $V$. dahliae have been considered to be important in pathogenesis by Verticillium (Tzima et al. 2011). When cotton cotyledons were treated with the culture supernatant of $V$. dahliae, whole $V$. dahliae culture (including supernatant and conidia, as positive control) and PDB (as negative control), respectively. The culture supernatant (Fig. 4c) caused typical symptoms such as dehydration, consistent with that caused by the whole culture (Fig. 4b), and brown discoloration of the vascular tissues in cotton stem sections (Fig. 4e). Because leaf wilt also is a key symptom of cotton plants infected with V. dahliae (Wang et al. 2004), we infiltrated a cotton leaf with $50 \mu \mathrm{L}$ of the culture supernatant, and the characteristic wilting was induced in cotton leaves within $24 \mathrm{~h}$ (Fig. 4g), These results indicated that a compound(s) in the supernatant was involved in cell death and wilt. 


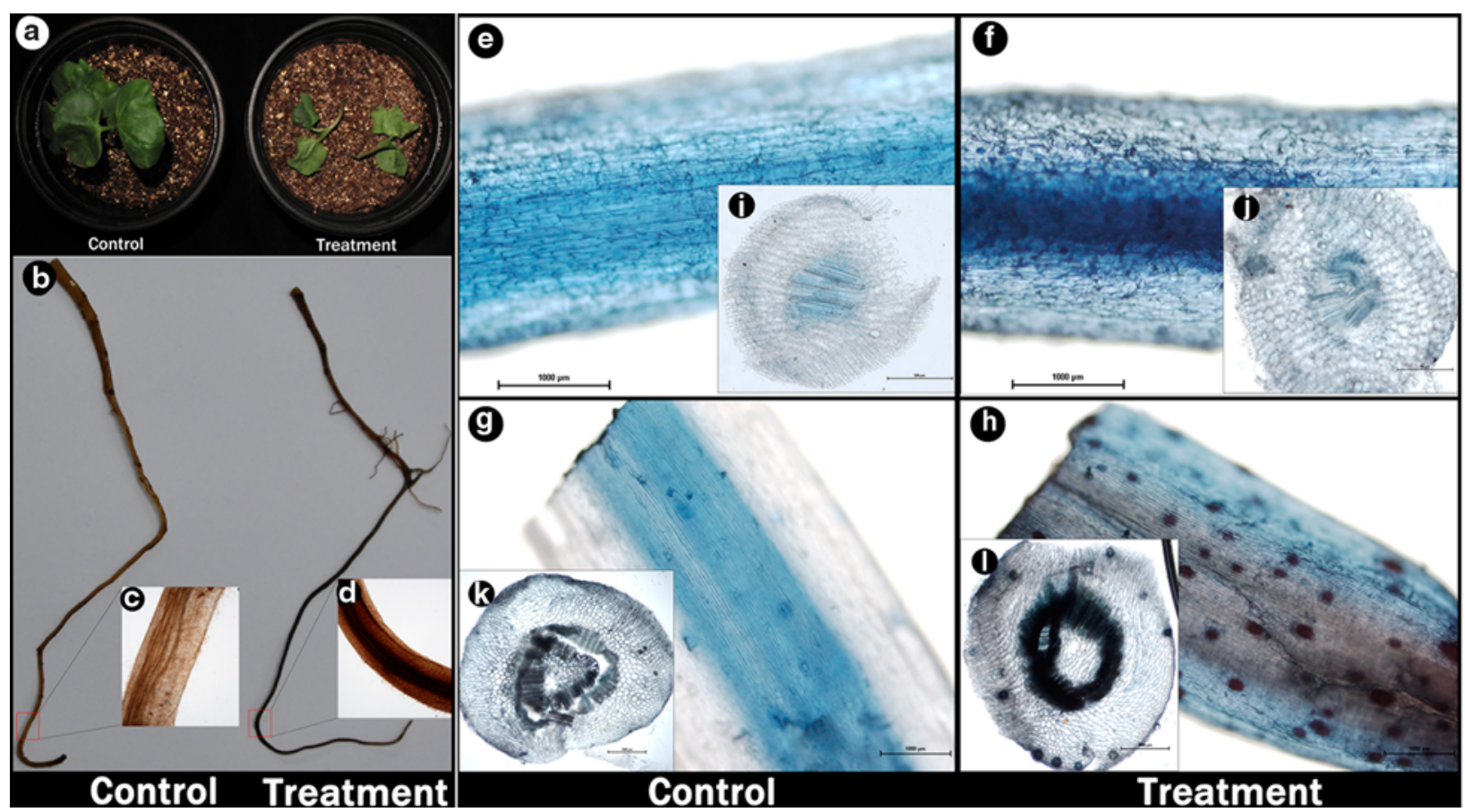

Fig. 3 Disease symptoms caused by Verticillium dahliae in cotton seedlings. a At $72 \mathrm{~h}$ after inoculation with $V$. dahliae. The control was treated with sterile distilled water instead of $V$. dahliae. b DABstained cotton roots showing $\mathrm{H}_{2} \mathrm{O}_{2}$ accumulation. c, d Light micrograph of $\mathrm{H}_{2} \mathrm{O}_{2}$ accumulation in the root sections. Longitudinal sections of infected cotton stained with trypan blue. $\mathbf{e}, \mathbf{f}$ roots, $\mathbf{g}, \mathbf{h}$ stems. $\mathbf{i}-\mathbf{l}$ Transverse sections of samples in $\mathbf{e}-\mathbf{h}$. Compared to control plants, significant, dense blue staining was observed around the vasculature of cotton roots infected by $V$. dahliae. Tests with DAB and trypan blue staining were repeated twice again to verify the result
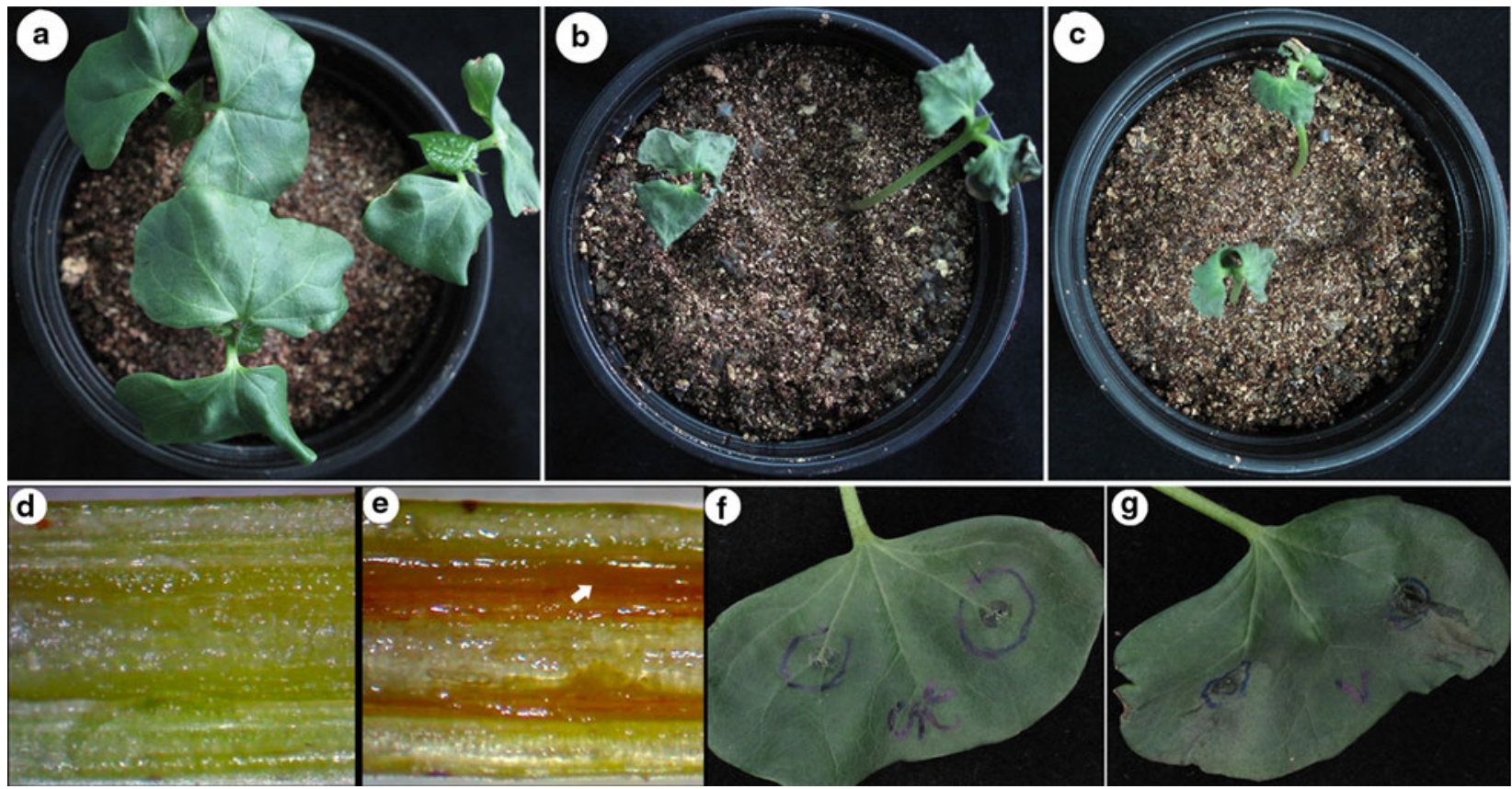

Fig. 4 Typical Verticillium symptoms were caused by the supernatant of a Verticillium dahliae culture. a No symptoms on the negative control inoculated with PDB only. b Wilt symptoms were induced by treatment with whole culture of $V$. dahliae as positive control. c Cotton cotyledons developed wilt symptoms after treatment with culture supernatant of $V$. dahliae. Three repetitions of the experiment gave consistent results. d No visible vessel discoloration was observed in cotton stem shown in
Fig. 4a. e Brown discoloration of vessel (white arrow) in longitudinal section of cotton stem in Fig. 4c. The above photographs were obtained $72 \mathrm{~h}$ after $V$. dahlia or supernatant inoculation. When cotyledons were infiltrated with supernatant, necrotic lesions developed on cotyledons (f), but no symptoms on the negative control (PDB infiltation) (g). Photographs ( $\mathbf{f}$ and $\mathbf{g}$ ) were obtained $24 \mathrm{~h}$ after infiltration. The leaf infiltration were done three times, respectively 


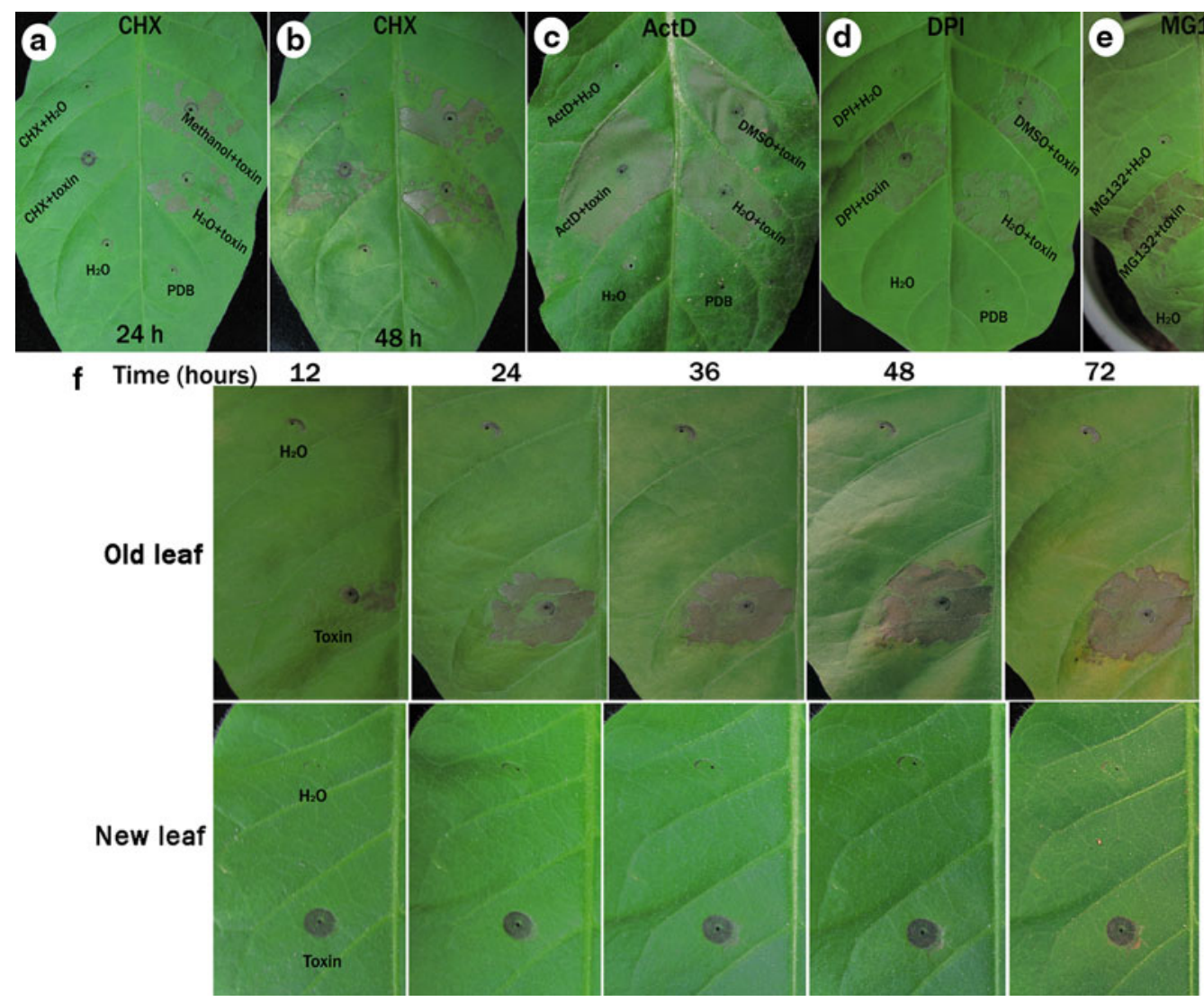

Fig. 5 Infiltration of old and new tobacco (Nicotiana tabacum cv. Xanthi) leaves with different inhibitors and analysis of inhibitory effect on lesion formation induced by Verticillium dahliae supernatant. a and b CHX $(50 \mu \mathrm{g} / \mathrm{mL})$ significantly inhibited lesion formation, but (c) ActD $(100 \mu \mathrm{g} / \mathrm{mL})$, d DPI $(5 \mu \mathrm{M})$ and e MG132

\section{$V$. dahliae supernatant triggers cell death}

by an age-dependent active process requiring

de novo protein synthesis

Necrotrophic pathogenic fungi are generally thought to use simpler mechanisms to destroy host tissue via a series of degrading enzymes or toxins (Oliver and Solomon 2010). However, recent studies have suggested that necrotrophic fungal pathogens can also manipulate the host during infection in subtle ways (Govrin and Levine 2000). To determine whether $V$. dahliae uses supernatant-induced cell death to manipulate its host, tobacco leaves were infiltrated with cycloheximide (CHX) (an inhibitor of protein synthesis) and actinomycin D (ActD) (an inhibitor of RNA synthesis), together with $V$. dahliae supernatant (Duval et al. 2005). CHX efficiently delayed the development of leaf lesions (Fig. 5a and $b$, CHX + supernatant) but ActD had no inhibitory effect (Fig. $5 \mathrm{c}$, ActD + supernatant), suggesting that $V$. dahliae supernatant-triggered cell death involves an active modification of the host (requiring de novo protein synthesis rather than new gene expression) and is not only the result of toxicity.
$(50 \mu \mathrm{M})$ did not. Images a and c-e were obtained $24 \mathrm{~h}$ after infiltration, image $\mathbf{b}$ was taken at $48 \mathrm{~h}$ after infiltration. $\mathbf{f} V$. dahliae supernatant induced leaf lesions in old and young leaves. Images were taken $0,24,48$, and $72 \mathrm{~h}$ after infiltration. The experiments were repeated at least three times with the same results

Some necrotrophic pathogens induce the ROS burst and HR cell death to facilitate their growth in host plants (Hammond-Kosack and Rudd 2008). To test whether cottongenerated ROS facilitate $V$. dahliae infection, we infiltrated tobacco leaves with diphenyleneiodonium chloride (DPI), an inhibitor of NADPH oxidase and of other flavoprotein enzymes, together with $V$. dahliae supernatant. DPI did not suppress $V$. dahliae supernatant-triggered lesions to any great extent (Fig. 5d, DPI + supernatant). This finding suggests that the ROS burst was likely a plant defense response from V. dahliae, not the cause of cell death (Dorey et al. 1999).

Previous studies have shown that the ubiquitin/26S proteasome system plays a central role in the activation of programmed cell death (PCD) by pathogens (Bos et al. 2010). However, the proteasome inhibitor MG132 did not prevent the induction of leaf lesions by the culture supernatant (Fig. 5e, MG132 + supernatant). These results suggest that the culture supernatant actively induces plant cell death by modifying protein synthesis in the host. This modification, however, does not involve the ROS burst or the ubiquitin/26S proteasome system. 
Interestingly, we observed that $V$. dahliae supernatant did not cause lesions on young leaves (Fig. 5f, young leaves). Moreover, lesions formed quicker on older leaves (Fig. 5f, old leaves), indicating that the supernatant-triggered cell death is correlated with leaf age. This finding is consistent with the observation that lesions and defoliation start at the base (old leaves) and move to the apex (young leaves) of the infected plant. However, the molecular mechanism is still unclear and needs further study.

In the present study, we investigated differential expression of proteins in cotton roots infected by $V$. dahliae. Some ROS-related proteins were upregulated after $V$. dahliae infection, and other proteins involved in normal metabolism or cell structure were downregulated. We further detected the release of ROS and death of cells in the cotton vasculature. Leaf wilt and brown discoloration of the vascular tissues were also caused by the supernatant of a $V$. dahliae culture. We used several inhibitors to analyze the mechanism by which the culture supernatant induced cell death in tobacco and found that lesion formation in tobacco leaves required de novo protein synthesis but not active gene expression. The fungus thus seems to regulate host protein synthesis to successfully infect cotton. Robb et al. (2012) considered that Verticillium wilt actually may be the result of an exaggerated plant response induced by $V$. dahliae. Based on the present results, however, toxins play a crucial role of Verticillium wilt, but the effective molecule or effectors in the toxins remain a scientific puzzle. Overall, our results suggest a new view of Verticillium wilt, and we will focus on identifying effectors of $V$. dahliae in further research.

Acknowledgments We are grateful to Prof. Xianming Deng (Department of Plant Protection, Southwest University, China) for the donation of the V9-strain of Verticillium dahliae and to Dr. Wangfeng Zhang (Shihezi University, China) for kindly providing the acid-delinted upland cotton seeds. This work was supported by Natural Science Foundation Project of CQ CSTC (Grant No. cstc2012jjA80021), PhD Initial Funding from Chongqing Normal University (Grant No. 12XLB002), the Key Foundation Project of Chongqing Normal University (Grant No. 2011XLZ09) and funding for scientific and technological research from the Chongqing Municipal Education Commission (Grant No. KJ120604).

Open Access This article is distributed under the terms of the Creative Commons Attribution License which permits any use, distribution, and reproduction in any medium, provided the original author(s) and the source are credited.

\section{References}

Acconcia F, Sigismund S, Polo S (2009) Ubiquitin in trafficking: the network at work. Exp Cell Res 315:1610-1618

Ahsan N, Lee DG, Lee KW, Alam I, Lee SH, Bahk JD, Lee BH (2008) Glyphosate-induced oxidative stress in rice leaves revealed by proteomic approach. Plant Physiol Biochem 46:1062-1070

Baniwal SK, Bharti K, Chan KY, Fauth M, Ganguli A, Kotak S, Mishra SK, Nover L, Port M, Scharf KD, Tripp J, Weber C, Zielinski D, von Koskull-Döring P (2004) Heat stress response in plants: a complex game with chaperones and more than twenty heat stress transcription factors. J Biosci (Bangalore) 29:471-487

Bos JIB, Armstrong MR, Gilroy EM, Boevink PC, Hein I, Taylor RM, Zhendong T, Engelhardt S, Vetukuri RR, Harrower B, Dixelius C, Bryan G, Sadanandom A, Whisson SC, Kamoun S, Birch PRJ (2010) Phytophthora infestans effector AVR3a is essential for virulence and manipulates plant immunity by stabilizing host E3 ligase CMPG1. Proc Natl Acad Sci USA 107:9909-9914

Bradford MM (1976) A rapid and sensitive method for the quantitation of microgram quantities of protein utilizing the principle of protein-dye binding. Anal Biochem 72:248-254

Candiano G, Bruschi M, Musante L, Santucci L, Ghiggeri GM, Carnemolla B, Orecchia P, Zardi L, Righetti PG (2004) Blue silver: a very sensitive colloidal Coomassie G-250 staining for proteome analysis. Electrophoresis 25:1327-1333

Cooper RM (2000) Verticillium-host interactions: past achievements and future molecular prospects. In: Tjamos EC, Rowe RC, Heale JB, Fravel DF (eds) Advances in Verticillium: research and disease management. APS Press, St Paul, pp 144-150

Coumans JVF, Polijak A, Raftery MJ, Backhouse D, Pereg-Gerk L (2009) Analysis of cotton (Gossypium hirsutum) root proteomes during a compatible interaction with the black root rot fungus Thielaviopsis basicola. Proteomics 9:335-349

Davletova S, Rizhsky L, Liang H, Shengqiang Z, Oliver DJ, Coutu J, Shulaev V, Schlauch K, Mittler R (2005) Cytosolic ascorbate peroxidase 1 is a central component of the reactive oxygen gene network of arabidopsis. Plant Cell 17:268-281

Dielen AS, Badaoui S, Candresse T, German-Retana S (2010) The ubiquitin/26S proteasome system in plant-pathogen interactions: a never-ending hide-and-seek game. Mol Plant Pathol 11:293-308

Dorey S, Kopp M, Geoffroy P, Fritig B, Kauffmann S (1999) Hydrogen peroxide from the oxidative burst is neither necessary nor sufficient for hypersensitive cell death induction, phenylalanine ammonia lyase stimulation, salicylic acid accumulation, or scopoletin consumption in cultured tobacco cells treated with elicitin. Plant Physiol 121:163-171

Duval I, Brochu V, Simard M, Beaulieu C, Beaudoin N (2005) Thaxtomin A induces programmed cell death in Arabidopsis thaliana suspension-cultured cells. Planta 222:820-831

El-kereamy A, Jayasankar S, Taheri A, Errampalli D, Paliyath G (2009) Expression analysis of a plum pathogenesis related 10 (PR10) protein during brown rot infection. Plant Cell Rep 28:95-102

Evans PJ, Whiteman M, Tredger JM, Halliwell B (1997) Antioxidant properties of $S$-adenosyl-L-methionine: a proposed addition to organ storage fluids. Free Radical Biol Med 23:1002-1008

Fradin EF, Thomma BPHJ (2006) Physiology and molecular aspects of Verticillium wilt diseases caused by $V$. dahliae and V. alboatrum. Mol Plant Pathol 7:71-86

Gao F, Zhou BJ, Li GY, Jia PS, Li H, Zhao YL, Zhao P, Xia GX, Guo HS (2010) A glutamic acid-rich protein identified in Verticillium dahliae from an insertional mutagenesis affects microsclerotial formation and pathogenicity. PLoS One 5:e15319

Gour HN, Dube HC (1985) Effects of ouabain and phytotoxic metabolites from Verticillium dahliae on the cell membranes of cotton plants. Physiol Plant Pathol 27:109-118

Govrin EM, Levine A (2000) The hypersensitive response facilitates plant infection by the necrotrophic pathogen Botrytis cinerea. Curr Biol 10:751-757 
Hammond-Kosack KE, Rudd JJ (2008) Plant resistance signalling hijacked by a necrotrophic fungal pathogen. Plant Signal Behav 3:993-995

Jang CH, Lee IA, Ha YR, Lim J, Sung MK, Lee SJ, Kim JS (2008) PGK1 induction by a hydrogen peroxide treatment is suppressed by antioxidants in human colon carcinoma cells. Biosci Biotechnol Biochem 72:1799-1808

Klosterman SJ, Atallah ZK, Vallad GE, Subbarao KV (2009) Diversity, pathogenicity, and management of Verticillium species. Annu Rev Phytopathol 47:39-62

McAlister L, Holland MJ (1982) Targeted deletion of a yeast enolase structural gene. Identification and isolation of yeast enolase isozymes. J Biol Chem 257:7181-7188

Meyer R, Slater V, Dubery IA (1994) A phytotoxic proteinlipopolysaccharide complex produced by Verticillium dahliae. Phytochemistry 35:1449-1453

Mur LAJ, Brown IR, Darby RM, Bestwick CS, Bi YM, Mansfield JW, Draper J (2000) A loss of resistance to avirulent bacterial pathogens in tobacco is associated with the attenuation of a salicylic acid-potentiated oxidative burst. Plant J 23:609-621

Murashige T, Skoog F (1962) A revised medium for rapid growth and bio assays with tobacco tissue cultures. Physiol Plant 15:473-497

Oliver RP, Solomon PS (2010) New developments in pathogenicity and virulence of necrotrophs. Curr Opin Plant Biol 13:415-419

Orozco-Cardenas M, Ryan CA (1999) Hydrogen peroxide is generated systemically in plant leaves by wounding and systemin via the octadecanoid pathway. Proc Natl Acad Sci USA 96:6553-6557

Pancholi V (2001) Multifunctional $\alpha$-enolase: its role in diseases. Cell Mol Life Sci 58:902-920

Qin GZ, Meng XH, Wang Q, Tian S (2009) Oxidative damage of mitochondrial proteins contributes to fruit senescence: a redox proteomics analysis. J Proteome Res 8:2449-2462

Rauyaree P, Ospina-Giraldo MD, Kang S, Bhat RG, Subbarao KV, Grant SJ, Dobinson KF (2005) Mutations in VMK1, a mitogenactivated protein kinase gene, affect microsclerotia formation and pathogenicity in Verticillium dahliae. Curr Genet 48: 109-116

Robb J, Shittu H, Soman KV, Kurosky A, Nazar RN (2012) Arsenal of elevated defense proteins fails to protect tomato against Verticillium dahliae. Planta 236:623-633

Ruan W, Lai M (2007) Actin, a reliable marker of internal control? Clin Chim Acta 385:1-5

Shigeoka S, Ishikawa T, Tamoi M, Miyagawa Y, Takeda T, Yabuta Y, Yoshimura K (2002) Regulation and function of ascorbate peroxidase isoenzymes. J Exp Bot 53:1305-1319

Short DM, Heron ID, Birse-Archbold JLA, Kerr LE, Sharkey J, McCulloch J (2007) Apoptosis induced by staurosporine alters chaperone and endoplasmic reticulum proteins: identification by quantitative proteomics. Proteomics 7:3085-3096

Street PFS, Cooper RM (1984) Quantitative measurement of vascular flow in petioles of healthy and Verticillium-infected tomato. Plant Pathol 33:483-492

Tarze A, Deniaud A, Le Bras M, Maillier E, Molle D, Larochette N, Zamzami N, Jan G, Kroemer G, Brenner C (2007) GAPDH, a novel regulator of the pro-apoptotic mitochondrial membrane permeabilization. Oncogene 26:2606-2620

Tchantchou F, Graves M, Falcone D, Shea TB (2008) S-adenosylmethionine mediates glutathione efficacy by increasing glutathione S-transferase activity: implications for $S$-adenosyl methionine as a neuroprotective dietary supplement. J Alzheimer's Dis 14:323-328

Tzima A, Paplomatas EJ, Rauyaree P, Kang S (2010) Roles of the catalytic subunit of cAMP-dependent protein kinase $\mathrm{A}$ in virulence and development of the soilborne plant pathogen Verticillium dahliae. Fungal Genet Biol 47:406-415

Tzima AK, Paplomatas EJ, Rauyaree P, Ospina-Giraldo MD, Kang S (2011) VdSNF1, the sucrose nonfermenting protein kinase gene of Verticillium dahliae, is required for virulence and expression of genes involved in cell-wall degradation. Mol Plant-Microbe Interact 24:129-142

Vallad GE, Subbarao KV (2008) Colonization of resistant and susceptible lettuce cultivars by a green fluorescent protein-tagged isolate of Verticillium dahliae. Phytopathology 98:871-885

van Wees S (2008) Phenotypic analysis of Arabidopsis mutants: trypan blue stain for fungi, oomycetes, and dead plant cells. Cold Spring Hard Protoc. doi:10.1101/pdb.prot4982

Varga A, Szabó J, Flachner B, Gugolya Z, Vonderviszt F, Závodszky P, Vas M (2009) Thermodynamic analysis of substrate induced domain closure of 3-phosphoglycerate kinase. FEBS Lett 583: 3660-3664

Wang JY, Cai Y, Gou JY, Mao YB, Xu YH, Jiang WH, Chen XY (2004) VdNEP, an elicitor from Verticillium dahliae, induces cotton plant wilting. Appl Environ Microbiol 70:4989-4995

Wilhelm S (1955) Longevity of the Verticillium wilt fungus in the laboratory and field. Phytopathology 45:180-181

Xie C, Wang D, Yang X (2009) Protein extraction methods compatible with proteomic analysis for the cotton seedling. Crop Sci 49:395-402

Zhang L, Ashendel CL, Becker GW, Morré DJ (1994) Isolation and characterization of the principal ATPase associated with transitional endoplasmic reticulum of rat liver. J Cell Biol 127:1871-1883

Zhou BJ, Jia PS, Gao F, Guo HS (2012) Molecular characterization and functional analysis of a necrosis- and ethylene-inducing, protein-encoding gene family from Verticillium dahliae. Mol Plant-Microbe Interact 25:964-975 